\title{
HIV PREVALENCE AMONG NEPALESE MIGRANT WORKERS WORKING IN NEPAL AND INDIAN CITIES
}

\author{
Gurubacharya D L*, Gurubacharya V L*
}

\section{ABSTRACT}

Several studies have shown an association between mobility and HIV infection. In this study, we examined the prevalence of HIV infection among migrant workers working in Nepal and Indian cities. A representative sample of 316 migrant men (210 internal migrants and 106 external migrants) were interviewed and tested for HIV infection during September 2001 to June 2003. HIV prevalence among migrants within Nepal was $2.3 \%$ as compared to $8.5 \%$ among migrants to India. $60 \%$ of migrants within Nepal and $85 \%$ of migrants to India have visited female sex workers. $75 \%$ of migrants within Nepal used condom while visiting female sex workers in comparision to only $10 \%$ of migrants to India. We also found limited access to HIV information service for migrant workers to India as compared to migrants within Nepal. Considering the high HIV prevalence and risky behaviours regarding HIV/AIDS among external migrants as compared to internal migrants, comprehensive HIV prevention programme is necessary for migrant workers going to work in India before they migrate.

\section{Key Words: HIV / AIDS, migration, sexual behaviours, Nepal, India.}

\section{INTRODUCTION}

In a span of less than three decades, HIV/AIDS has emerged as the single most formidable challenge to public health, human rights and development in the new millennium. ${ }^{1}$ By the end of 2003, it was estimated that 37.8 million people (range: 34.642.3 million) across the world were living with HIV and 61000 of these people were living in Nepal. ${ }^{2}$

Migration is one of many social factors that have contributed to the AIDS epidemic. . $^{3,4}$ Two recent studies have examined its role in the spread of HIV. ${ }^{6,7}$ In recent years, increasing numbers of people have been on the move- from place to place within their own country, or to different countries altogether. The International Organization for Migration estimates that the number of international migrants (those who crossed national borders) increased from 105 million in 1985 to 175 million in 2000 , while a similar number of people may move within national borders. ${ }^{2}$

Broadly the migration pattern in Nepal is divided into two categories: External migration (those who cross national borders) and internal migration (those who move within national borders). ${ }^{8}$ It is estimated that as many as one million Nepalese currently migrate to India for employment, while the volume of internal migrants in Nepal is estimated at 1.2 million. ${ }^{8}$ Most migrants are men, and most migration is circular, i.e. men work away from home and family for periods of several months, returning briefly for major festivals or to harvest crops. ${ }^{9}$

The national HIV/AIDS strategy (2002-2006) in Nepal has identified migrant populations, especially labour migrants to India, as one of the vulnerable groups for HIV infection. ${ }^{10}$ Two

* STI / AIDS Counseling and Training Service (SACTS), Kathmandu, Nepal.

Address for correspondence : Dr. Dipesh L. Gurubacharya

STI / AIDS Counseling and Training Service (SACTS), Kathmandu, Nepal

P.O. Box: 7314, Kathmandu, Nepal.

Email: dipeshlal@wlink.com.np 
studies have examined the prevalence of HIV among male migrant returnees from India and revealed HIV prevalence of $3.7 \%$ and $10.3 \%$ respectively. ${ }^{11,12}$ However, there is little data on the seroprevalence of HIV among the internal migrants. In one study the seroprevalence of HIV infections among male internal migrants revealed about $3 \% .^{11}$

The objectives of this study were to measure the seroprevalence of HIV infections and to assess the behavioural risk factors for HIV infection among Nepalese migrant workers working in Nepal and Indian cities.

\section{MATERIALS AND METHODS}

This study was conducted by SACTS (STI/AIDS Counselling and Training Service). SACTS is a non-profit making nongovernmental organization for prevention of sexually transmitted infections (STIs) and Acquired Immune Deficiency Syndrome (AIDS). It offers professional training, counselling and research related with these activities. It is also committed in community based targeted intervention programme for the control of STI/AIDS and carries out information, education and communication activities.

Total of 316 male migrant workers who visited or referred to counselling and treatment clinic in SACTS for symptoms of sexually transmitted infections during September 2001 to June 2003 were interviewed. Among 316 migrants, 210 were internal migrants from different parts of Nepal working in Kathmandu valley and 106 were external migrants working in different cities of India. External migrants were in Nepal for brief period of time during this study.

Data collection was carried out using a standardized questionnaire. The questionnaire was in Nepali language and consisted of socio-demographic background, migration histories, access to HIV information services and risk behaviours related to HIV/AIDS. The respondents were informed about the study procedures and after informed consent were obtained to participate in the study; all the respondents were tested for HIV antibodies.

Two milliliters of venous blood were taken from all the participants and were screened for HIV antibodies with commercial ELISA test (HIV 1.2.0) in the laboratory of SACTS. All the positive samples were confirmed by additional ELISA test.

\section{RESULTS}

Between September 2001 and June 2003, 316 male migrants were recruited for the study. Among the 316 migrant workers, 210 were internal migrants and 106 were external or circular migrants. Table I shows the age group distribution of study population along with their HIV infection status. Migration was highest among those subjects aged 20-29 years for both internal and external migrants. More HIV cases were also seen in the same age group in both internal and external migrants.

Of 106 external migrants, 32 reported Mumbai as their destination. Of these 32 migrants to Mumbai, 4 (12.5\%) were positive for HIV antibodies. Remaining of 74 external migrants were working in different other cities of India at the time of study (Table II).

$90 \%$ of the migrants within Nepal and $68 \%$ to India have heard about HIV. $60 \%$ of the migrants within Nepal and $85 \%$ to India have visited female sex workers (Fig. 1).

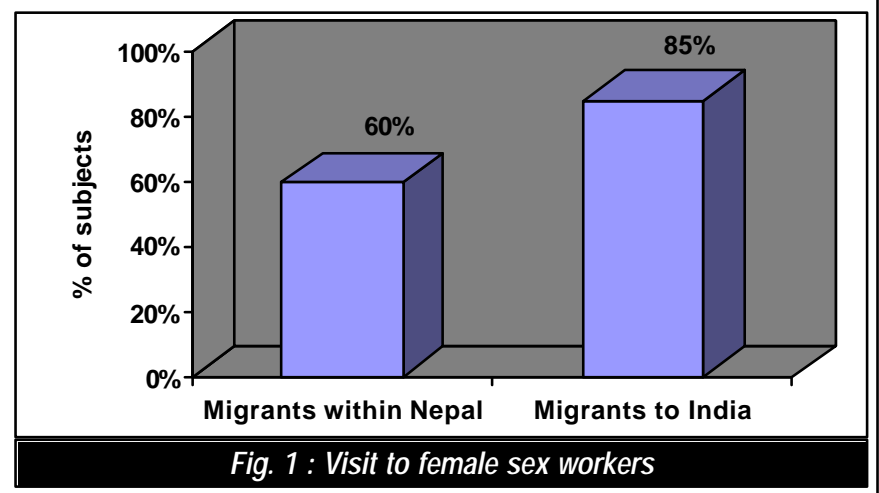

Table I : Age group distribution

\begin{tabular}{cc|c|c|c}
\hline $\begin{array}{c}\text { Age Group } \\
\text { (yrs.) }\end{array}$ & $\begin{array}{c}\text { Migrants within } \\
\text { Nepal }\end{array}$ & HIV +ve & $\begin{array}{c}\text { Migrants to } \\
\text { India }\end{array}$ & HIV +ve \\
\hline$<20$ & 6 & - & 2 & - \\
\hline $20-29$ & 130 & 4 & 56 & 5 \\
\hline $30-39$ & 70 & 1 & 45 & 4 \\
\hline$>40$ & 4 & - & 3 & - \\
\hline Total & $\mathbf{2 1 0}$ & $\mathbf{5}$ & $\mathbf{1 0 6}$ & $\mathbf{9}$ \\
\hline
\end{tabular}

Table II : Migrants destination within India

\begin{tabular}{cc|cc}
\hline City & Number & HIV + ve & Percentage \\
\hline Mumbai & 32 & 4 & 12.5 \\
\hline Other Cities & 74 & 5 & 6.75 \\
\hline
\end{tabular}


In average migrants within Nepal visited female sex workers once in 3 months in comparison to migrants to India who visited female sex workers at least once in a month. $75 \%$ of migrants within Nepal used condoms while visiting female sex workers in comparison to only $10 \%$ of migrants to India (Fig.2).

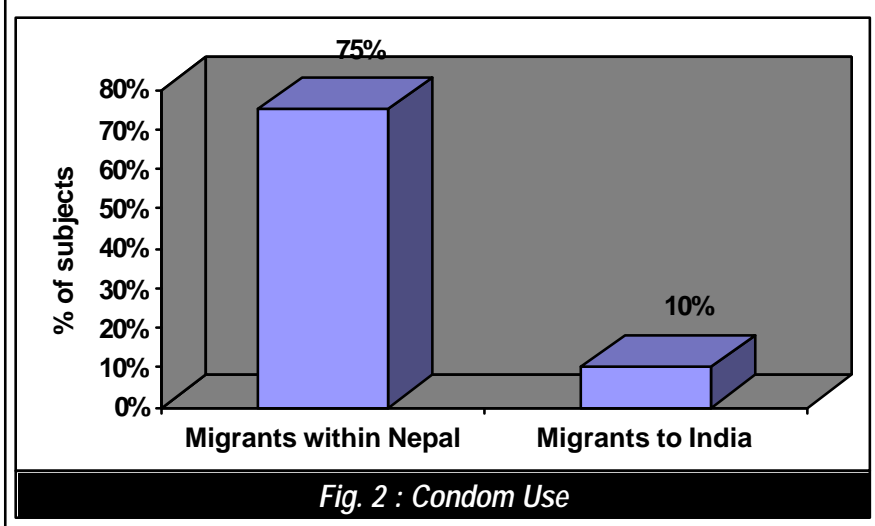

$64.7 \%$ of the migrants within Nepal have access to HIV information services but only $14.1 \%$ of migrants to India have access to HIV information services (Fig. 3).

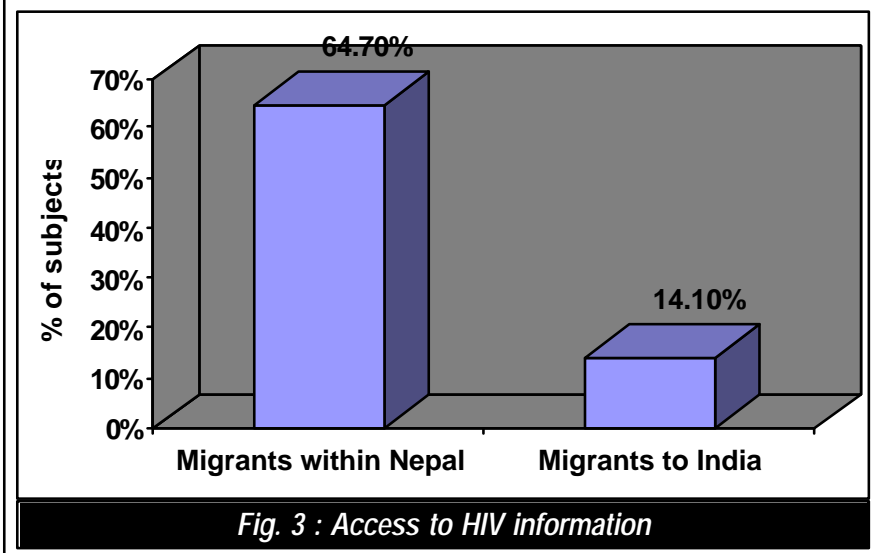

The overall prevalence of HIV infection in migrant workers was $4.4 \%$. When the HIV prevalence was disaggregated by migration status, $2.3 \%$ of internal migrants and $8.5 \%$ of external migrants were HIV infected (Fig. 4).

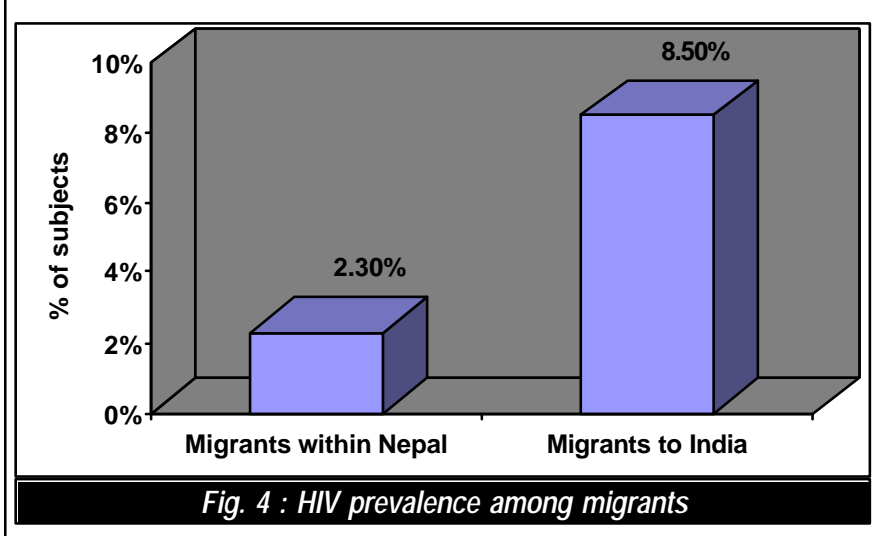

\section{DISCUSSION}

Our study revealed a high prevalence of HIV infection $(8.5 \%)$ among external migrants as compared to internal migrants (2.3\%). This high HIV prevalence among external migrants suggests that migrants' population to India are more vulnerable to HIV infection. Not only was the migration to India the cause for high prevalence of HIV infection but also the migrants' destination in India was the contributing factor. In our study most of the external migrants reported Mumbai as their destination where the reported HIV prevalence among female sex workers is the highest among the Indian cities. ${ }^{12}$ In Mumbai HIV prevalence among female sex workers reached $71 \%$ in 1997. ${ }^{13}$

This study also revealed high-risk behaviours among external migrants compared to internal migrants. $60 \%$ of migrants within Nepal and $85 \%$ of migrants to India visited female sex workers. In average migrants within Nepal visited female sex workers once in three months in comparison to migrants to India who visited female sex workers at least once in a month. $75 \%$ of internal migrants used condom while visiting female sex workers in comparison to only $10 \%$ of migrants to India. Similar findings were found in the study done in migrantreturnees from India. ${ }^{11,12,14}$ Migrants and mobile people may have little or no access to HIV information, health services, and means of HIV/AIDS prevention (condom, treatment of sexually transmitted infections). ${ }^{14}$ In this study also $64.7 \%$ of the migrants within Nepal have access to HIV information services but only $14.1 \%$ of migrants to India have access to HIV information services. Being mobile in and of itself is not a risk factor for HIV/AIDS; it is the situations encountered and the behaviours possibly engaged in during mobility or migration that increase vulnerability and risk regarding HIV/ AIDS. ${ }^{15}$

In conclusion, this study documented high HIV prevalence among external migrants as compared to internal migrants. Because of external migrants risky sexual behaviours (including unprotected sex with female sex workers), low level of awareness regarding HIV/AIDS transmission and prevention, and difficulties in accessing treatment for HIV while away from home as compared to internal migrants, external migrants are more vulnerable to HIV/AIDS, and serving as a "bridge" for HIV transmission into their communities. Considering the external migrants risky behaviours regarding HIV/AIDS as compared to internal migrants that may spread HIV into their communities, it is essential to initiate comprehensive HIV programme about information and prevention of HIV infection and use of condom 
to approach and educate migrant workers to India. And this comprehensive HIV programme should be provided to migrant workers before they migrate to India.

\section{ACKNOWLEDGEMENTS}

The authors would like to acknowledge the generous contributions of staffs of SACTS, Dr. Ritu Gongal and Dr. Angel Magar, without the hard work of whom this study would not have been possible.

\section{REFERENCES}

1. UNDP. HIV/AIDS and Development in South Asia: Regional Human Development Report. 2003.

2 UNAIDS. Report on the Global AIDS epidemic: $4^{\text {th }}$ Global report. June 2004.

3. Decosas J, Adrien A. Migration and HIV. AIDS 1997; 11 (suppl A) : S77-S84.

4. Mabey D, Mayaud P. Sexually transmitted diseases in mobile populations. Genitourin Med 1997; 73: 18-22.

5. Lurie MN, Williams BG, Zuma K et al. The impact of migration on HIV-1 transmission in South Africa: a study of migrant and nonmigrant men and their partners. Sexually Transmitted Diseases 2003; 30: 149-156.

6. Lydie N, Robinson NJ, Ferry B, Akam E et al. Mobility, sexual behaviour, and HIV infection in an urban population in Cameroon. J Acquir Immune Defic Syndr 2004; 35: 67-74.
7. Lurie $\mathrm{MN}$, Williams BG, Zuma $\mathrm{K}$ et al. Who infects whom? HIV-1 concordance and discordance among migrant and nonmigrant couples in South Africa. AIDS 2003; 17: 2245-2252.

8. Pokharel BJ, Aryal S, Bhattarai A, Pyakuryal A, Suvedi BK. Situation Analysis of HIV/AIDS in Nepal. Final Draft. Teku, Kathmandu: National Centre for AIDS and STD Control, December 2000 .

9. Estelle AS, Gruskin S. Vulnerability to HIV/STIs among rural women from migrant communities in Nepal: A health and human rights framework. Reproductive Health Matters 2003; 11: 142-151.

10. National Centre for AIDS and SID Control (2003). National HIV/AIDS strategy (2002-2006) Nepal. Ministry of Health, National Centre for AIDS and SID Control.

11. Basnet J, Gurubacharya VL. HIV/AIDS prevalence and risk factors among migrant and non-migrant males of Achham district in far-western Nepal. Volume-1. Report submitted to Family Health International/Nepal. New Era. 2002.

12. Poudel KC, Okumura J, Sherchand JB, Jimba M, Murakami I, Wakai S. Mumbai disease in far western Nepal: HIV infection and syphilis among male migrant-returnees and non-migrants. Tropical Medicine and International Health 2003; 8: 933-939.

13. Schwartlander B, Garnett G, Walker N, Anderson R. AlDS in a new millennium. Science 2000; 289: 64-66.

14. Poudel KC, Jimba M, Okumura J, Joshi AB, Wakai S. Migrants' risky behaviours in India and at home in far western Nepal. Tropical Medicine and International Health 2004; 9: 897-903.

15. UNAIDS. Population, Mobility and AIDS: Technical update. 2001 . 